\title{
Ditadura Militar no Brasil: debatendo os ataques à autonomia sindical e aos direitos trabalhistas
}

\author{
The Military Dictatorship in Brazil: debating the attacks \\ on trade union autonomy and labor rights
}

\author{
Cleier Marconsin*
}

\begin{abstract}
Resumo- O texto trata dos direitos trabalhista e sindical durante a Ditadura Militar e no processo das lutas pelo seu fim. Entendendo a história como solo vivo onde se movem as classes sociais em seus conflitos e lutas, os direitos do trabalho são tratados como parte intrínseca dos direitos sociais e como conquistas dos trabalhadores na sociedade capitalista, em confronto com as necessidades da acumulação monopolista, no processo mesmo de reconhecimento da questão social. Durante a autocracia burguesa, a perda de direitos conquistados arduamente pelos trabalhadores brasileiros ocorreu através da repressão e da cooptação. Entretanto, setores combativos resistiram, fortalecendo-se quando a crise internacional do capital rebate em sua dinâmica e, com movimentos grevistas, apressaram o processo de transição. Fechando o ciclo das lutas pelo fim da Ditadura, a Constituição Federal de 1988 trouxe conquistas para os direitos do trabalho, mas sua materialização tem sido dificultada e até obstaculizada pela burguesia.
\end{abstract}

Palavras-chave: trabalho; direitos; ditadura.

\begin{abstract}
The paper deals with the labor and union rights during the military dictatorship and in the process of fighting for his end. Understanding history as living soil where the social classes move in their conflicts and struggles, labor rights are treated as an intrinsic part of social rights and as achievements of workers in capitalist society, in conflict with the needs of monopolistic accumulation, in the process of recognition of the social question. During the bourgeois autocracy, the loss of hard-won rights by Brazilian workers occurred through repression and co-optation. However, militant sectors resisted, became strong when the international crisis of capital bounced on its dynamics and, with strike movements, hastened the transition process. Closing the cycle of struggles at the ending of the dictatorship, the Federal Constitution of 1988 brought victories for labor rights, but its realization has been hampered and hindered by the bourgeoisie.
\end{abstract}

Keywords: labor; rights; dictatorship.

\footnotetext{
* Assistente Social. Doutora em Serviço Social. Professora-adjunta da Faculdade de Serviço Social (FSS) da UERJ. Pesquisadora do Observatório do Trabalho no Brasil/FSS/UERJ. Correspondência: Universidade do Estado do Rio de Janeiro, Centro de Ciências Sociais - Faculdade de Serviço Social - DFTPSS. Rua São Francisco Xavier, 524 - sl.8020 - D, Maracanã - Rio de Janeiro, RJ. CEP: 20550013. E-mail: <cleiermarconsin@gmail.com>
} 


\section{Introdução}

Este texto traz o debate sobre as condições dos direitos do trabalho durante a Ditadura Militar no Brasil, cujo golpe que a instaurou completou 50 anos em $1^{\circ}$ de abril de 2014 , e as lutas sociais que fizeram parte de seu fim. Intenciona-se, assim, contribuir, no âmbito do Serviço Social, para a construção de um bloco de análise crítica sobre as condições dos direitos do trabaIho, no Brasil, tendo como foco as legislações trabalhista e sindical nesse período.

Sem a pretensão de esgotar a temática, ao perscrutar a realidade numa perspectiva de totalidade, tendo a história como solo vivo onde se movem as classes sociais em seus conflitos e lutas, os direitos do trabalho são tratados, aqui, como parte intrínseca dos direitos sociais e como conquistas dos trabalhadores na sociedade capitalista em confronto com as necessidades da acumulação monopolista, no processo mesmo de reconhecimento da questão social. Ao mesmo tempo, embora seu recorte espacial seja a sociedade brasileira, e o temporal, a Ditadura Militar, procura-se mostrar a relação de sinergia que existe entre os direitos conquistados aqui e aqueles conquistados pelos trabalhadores dos países capitalistas centrais, onde esse modo de produção hoje hegemônico tem origem. Ou seja, buscase entender a gênese dos direitos do trabalho nos países de origem do capitalismo, centros nervosos das revoluções burguesas e das primeiras lutas dos trabalhadores contra a exploração, seu espraiamento pelas sociedades periféricas que se industrializam de acordo com suas peculiaridades, enfrentando as dificuldades inerentes à luta de classes que se processam nelas, com foco no Brasil.

Com início ainda no século XIX, mas principalmente no século XX, o protagonismo dos trabalhadores foi fundamental para a ampliação dos direitos de cidadania (civis e políticos) ${ }^{1}$ à sua classe, como liberdade de reunião, de partidos, de filiação partidária e outros, antes restritos aos proprietários. Nesse mesmo caminho se deu a conquista dos direitos sociais; dentre eles, os do trabalho, contra a vontade da burguesia, que foi responsável pela criação daqueles referentes à cidadania, restritos à sua classe, na medida em que os trabalhadores ganharam consciência da importância do trabalho, na sociedade voltada para a acumulação do capital.

Uma forma inicial e mais elementar de luta encetada pelos trabaIhadores esteve voltada contra as máquinas, através do movimento denominado luddismo, cujo nome derivou da sua liderança, Ned Ludd, um operário que desenvolveu essa estratégia ${ }^{2}$, a qual foi superada pela orga-

\footnotetext{
'Os direitos de cidadania, que incluem os direitos civis e políticos, foram os primeiros a existir com base na filosofia iluminista e na tradição liberal, no processo mesmo de superação das sociedades baseadas em relações feudais e os estados absolutistas pela modernidade burguesa. São denominados por N. Bobbio como direitos de primeira geração. (MARCONSIN, 2009)

${ }^{2}$ Embora tivesse maior preponderância na Inglaterra, onde a utilização de máquinas era mais generalizada, observase a sua existência nas primeiras décadas do século XIX também na França, na Bélgica, na Alemanha e até na Suiça. (HOBSBAWM, 2000)
} 


\section{ReVistg all paUtg}

\} DITADURA MILITAR NO BRASIL - MARCONSIN, C. \}

nização sindical e adoção de outras, como a greve. Após esse momento, a diminuição da jornada de trabalho foi a primeira reivindicação a ganhar corpo na sociedade do capital. De fato, se é o tempo de trabalho socialmente necessário que viabiliza a mais-valia, seja na forma absoluta, seja na forma relativa, inicialmente, as lutas pela diminuição da jornada voltaram-se para barrar o exaurimento dos trabalhadores. Mas como a economia de força de trabalho é central para a acumulação capitalista, produzindo o exército industrial de reserva, as lutas voltaram-se, da mesma maneira, para a ampliação de postos de trabalho. Aos trabalhadores interessa limitar e encurtar a jornada de trabalho, contrapondo-se aos interesses da acumulação em ampliar o exército industrial de reserva. Assim, segundo Marx (1988):

A criação de uma jornada normal de trabalho é [...] produto de uma guerra civil de longa duração, mais ou menos oculta, entre a classe capitalista e a classe trabalhadora. Como a luta foi inaugurada no âmbito da indústria mais moderna, travou-se primeiro na terra natal dessa indústria, na Inglaterra. (p. 227)

Espraiando-se para outros países da Europa e das Américas, para Marx (1988, p. 181), a diminuição da jornada extensiva torna-se razão para a intensificação do trabalho, outra forma de extração de mais-valia absoluta, imposta pela burguesia para aumentar a produtividade. Mesmo assim, ele considera tal luta um marco na história da produção capitalista: é "uma luta entre o capitalista coletivo, isto é, a classe dos capitalistas, e o trabalhador coletivo, ou a classe trabalhadora". Sendo um marco na luta de classes, ao longo do processo sócio-histórico, deu início, também, ao que Marx (1988) denomina de legislação fabril, precursora das legislações trabalhistas constituídas posteriormente.

Em meados do século XIX, as lutas estavam acirradas e os trabaIhadores tinham a redução da jornada como centro, juntamente com outras questões que começaram a se colocar em função da ausência total de direitos vivida pela classe trabalhadora. É verdade que a derrota das revoluções proletárias de $1848^{3}$ provocou um refluxo do movimento durante longo tempo, todavia, como aponta Netto $(1992$, p. 51) nos anos sessenta superase o refluxo, "como o indica a Associação Internacional dos Trabalhadores".

Inicia-se, então, um largo processo, que só estará consolidado às vésperas da Primeira Guerra Mundial, pelo qual a classe operária vai elaborar os seus dois principais instrumentos de intervenção sóciopolítica, o sindicato e o partido proletário.

\footnotetext{
3 "A República social apareceu como palavreado, como profecia, no limiar da Revolução de Fevereiro. Nos dias de junho de 1848, ela foi afogada no sangue do proletariado parisiense, mas ronda, como fantasma, os atos subsequentes do drama". (MARX. 1983).
} 


\section{hevistg all pgutg}

\} DITADURA MILITAR NO BRASIL - MARCONSIN, C.

Dessa forma, a partir da organização dos partidos e do movimento sindical - primeiro movimento social da modernidade - a ortodoxia liberal, vigente no período, começa a ser questionada e os direitos sociais têm início de maneira mais avançada.

Para Vianna (1978, p. 6), o liberalismo foi compelido a assimilar a democracia. $\mathrm{O}$ autor identifica esse fenômeno porque os dois conceitos não são coincidentes, tanto em relação ao "significado" quanto à "sua produção na história do pensamento político". As atuais democracias liberais primeiro foram liberais e, posteriormente, tornaram-se democráticas, já que a abertura do pacto liberal deu-se por força da ação de movimentos sociais até então situados fora do sistema político. Ao tratar dessa diferença, Dias (2006, p. 15) lembra a posição do "teórico elitista Ortega y Gasset, em La rebelión de las massas", que assim se referia: "No século dezenove os liberais estavam no poder e os democratas na cadeia". Essa ideia significava que os liberais pertenciam às classes dominantes e os democratas ou pertenciam à "minoria burguesa" ou ao "proletariado organizado". Não havia coincidência entre liberalismo e democracia, sendo que a polarização intensa entre os dois sistemas começou a se dar, ainda segundo o autor, "a partir do momento em que os subalternos não se conformam mais em viver passivamente, mas desejam redefinir seu local na Ordem" burguesa.

Assim, o movimento que determinou uma intervenção mais incisiva do Estado, para Netto (1992, p. 31), nasceu do "novo dinamismo político e cultural que passou a permear a sociedade burguesa [...]", mas explicitou, no processo, a confluência de "exigências econômico-políticas próprias da idade do monopólio" com o "protagonismo político-social das camadas de trabalhadores, especialmente o processo de lutas e de autoorganização da classe operária", seja através de partidos, seja através dos sindicatos.

Também no Brasil, as origens históricas dos direitos trabalhistas ligam-se ao reconhecimento da questão social, fenômeno nascido das grandes transformações pelas quais passou a sociedade brasileira de fins do século XIX e início do XX, no bojo do complexo processo de sucessão do capitalismo concorrencial pelo monopolista, desencadeado em nível mundial. A legislação trabalhista e a sindical - imbricadas uma na outra - e as políticas sociais; importantes elementos que, na dinâmica da luta de classes, se combinam historicamente com a repressão policial, também são fruto das lutas dos trabalhadores.

Para Giannotti (2007, p. 104), a luta mais destacada dos trabaIhadores brasileiros em fins do século XIX e início do XX, como em termos internacionais, foi pelas 8 horas de trabalho. Afirmativa compartilhada por Antunes (1985, p. 49 - grifos nossos) para quem nos "vários Congressos Sindicais e Ope-rários e nas inúmeras manifestações grevistas tornaram-se constantes as rei-vindicações visando a melhoria salarial e a redução da jornada de trabalho" (grifos nossos). A partir de 1890, nota-se a redução da 


\section{peVistg all paUtg}

\} DITADURA MILITAR NO BRASIL - MARCONSIN, C. \}

jornada no centro das lutas ${ }^{4}$. Ao mesmo tempo, a busca pela organização sindical tornou-se uma constante entre os trabalhadores, sendo sua primeira regulação legal aprovada em 1907. Como observa Vianna (1978, p. 50), nessa lei encontra-se o embrião da intervenção do Estado, já que os trabalhadores eram "obrigados a registrar seus estatutos e a enviar relação de membros de sua diretoria à repartição competente" e a "pautarem-se pelos princípios da harmonia ente o capital e o trabalho".

Após a Revolução Russa (ocorrida em 1917), já no ano de 1919, uma legislação voltada para responsabilização das empresas pelos acidentes de trabalho foi aprovada e a luta pela diminuição da jornada de trabalho também trazia resultados. Apesar de apresentar diferenças por ramos de atividade, no início do século XX, a jornada era de 14 horas; em 1911 era de 11 horas e, em 1920, de 10 horas.

Sem a pretensão de superestimar o protagonismo dos trabalhadores, entendemos que as lutas, apesar da dura repressão, fossem elas realizadas através de greves localizadas ou gerais, sabotagens, publicações periódicas de jornais e revistas anarquistas e comunistas etc., engendraram, juntamente com determinações econômicas e políticas nacionais e internacionais, desde fins do século XIX, mas principalmente nas duas primeiras décadas do XX, a possibilidade do aparecimento da classe trabalhadora no cenário político brasileiro. No bojo desse contexto, observamos o reconhecimento da questão social por parte do Estado e da burguesia e sua configuração, também no Brasil, através da consolidação de legislação trabalhista, bem como da implantação de medidas de política social, especialmente após o Movimento Político-Militar de 1930. Ao mesmo tempo, é visível que a relação de forças alcançada pelos trabalhadores organizados não foi suficiente para garantir uma legislação mais ampla, mais inclusiva e impedir o controle dos sindicatos pelo Estado na legislação sindical. Não impediu, também, que o Estado Novo se implantasse e que incidisse com grande violência sobre os trabalhadores organizados que apresentavam dissidências em relação à condução política imposta.

Demonstra isso a Consolidação das Leis do Trabalho (CLT), de 1943 - aprovada durante o Estado Novo - que incorporou várias reivindicações históricas dos trabalhadores brasileiros ${ }^{5}$ como: regulamentação da jornada de trabalho em 08 horas; regulamentação do trabalho de muIheres e de adolescentes e proibição do trabalho infantil; descanso semanal remunerado; férias; acidentes de trabalho; estabilidade no emprego com indenização por demissão ${ }^{6}$ e aposentadoria. Entretanto, juntamente com a

\footnotetext{
${ }^{4}$ Acompanhava-a outras lutas, como a defesa do poder aquisitivo dos salários, proibição do trabalho infantil, regulamentação do trabalho de mulheres e menores de idade, direito a férias, seguro contra acidente de trabalho, doença profissional e pela consecução do contrato coletivo de trabalho.

${ }^{5}$ Ficaram excluídos os funcionários públicos, servidores de autarquias paraestatais - que possuíam regime próprio - mas também os trabalhadores rurais e de serviços domésticos.

${ }^{6}$ Trabalhador "que contar com um determinado número de anos de efetivo serviço, somente poderá ser despedido mediante a existência da justa causa judicialmente apurada" (VIANNA, 1978).
} 


\section{Revista pll paעtg}

\} DITADURA MILITAR NO BRASIL - MARCONSIN, C. \}

normatização desses direitos, muitos dos quais já existiam em leis esparsas, daí o termo consolidação, foi imposta uma legislação sindical que atrelou os sindicatos ao Estado, anulando sua autonomia e independência, ao mesmo tempo em que prendeu, torturou e assassinou os dissidentes políticos ${ }^{7}$.

Desde o fim do Estado Novo, com a redemocratização ocorrida em 1945, passando pelo governo eleito de Getúlio Vargas, de Juscelino Kubitscheck, de Janio Quadros e João Goulart, além da estabilidade no emprego, que ganhou status constitucional, os trabalhadores conquistaram o $13^{\circ}$ salário, reivindicação central do movimento sindical desde 1953. Isto após uma greve, considerada por muitos autores como a primeira greve geral do Brasil, já que envolveu trabalhadores em nível nacional ${ }^{8}$, e avançaram em termos de organização sindical.

Observa-se, em especial a partir de inícios da década de 1960, um salto de qualidade em termos de organização sindical, com a criação do Comando Geral dos Trabalhadores (CGT) - que avançava na constituição de uma central dos trabalhadores -, atuando juntamente com o Pacto de Unidade e Ação (PUA) e outras associações regionais, sendo a região do $A B C$ paulista a mais combativa. Além dos estudantes, que participavam ativamente através da União Nacional dos Estudantes (UNE), operava-se crescente politização dos setores urbanos médios, com a formação de movimentos sociais diversos, de mulheres, contra a carestia etc. Em termos de organização sindical, os avanços no campo também foram significativos, bem como a luta pela terra.

Observa-se, pois, no período, um quadro de efervescência político-social por parte dos trabalhadores que não poderia deixar de preocupar a burguesia brasileira, voltada historicamente a mantê-los excluídos da vida política nacional. Afinal, como mostra Fernandes (2006, p. 385386), no Brasil o "consenso burguês mostrou-se invariavelmente tímido e hostil" às pressões vindas "de baixo" em função do seu "temor de classe". A burguesia não se colocava frente ao "problema da democracia (mesmo entendida como uma 'democracia burguesa')", mas ao "problema da ordem", ou seja, de uma "ordem burguesa" que "devia ser salva", equilibrada e "consolidada". Dessa forma, ainda para Fernandes (2006, p. 385-386), a burguesia brasileira, desde a crise da Primeira República - com raros e curtos intervalos - agiu através de "pressões de cima para baixo", sempre buscando submeter os trabalhadores "ao controle institucional da dominação e do poder", sustentando-se por mecanismos de "opressão e repressão, normais ou extraordinários, do Estado nacional". Essa ordem assim constituída teve poucos avanços em relação às condições vividas pelas socie-

\footnotetext{
${ }^{7}$ Apesar das prisões atingirem qualquer pessoa que se opusesse ao governo, em especial, as prisões, tortura e mortes de comunistas eram uma constante, indo além de 1937. É parte desse processo a prisão e a deportação de Olga Benário aos campos de extermínio nazistas (MARCONSIN, 2009).

${ }^{8}$ Greve dirigida pela Confederação Nacional dos Trabalhadores na Indústria (CNTI), pelo Pacto de Unidade e Ação (PUA) e outras articulações sindicais regionais, em julho de 1962 (GIANNOTTI, 2007).
} 


\section{peVistg all paUtg}

\} DITADURA MILITAR NO BRASIL - MARCONSIN, C. \}

dades capitalistas centrais, sendo seu fundamento uma permanente relação de controle e tutela sobre a "classe dos outros".

Dessa maneira, as tensões econômicas, os conflitos, as lutas políticas e sociais nacionais, mas também internacionais, no período diretamente anterior ao Golpe, engendraram, para Netto (1991, p. 26), uma crise da forma de dominação burguesa no país. Por um lado, a burguesia nacional dirigente encontrava-se tensionada pela necessidade de definir-se entre um modelo de acumulação capitalista nacionalista, independente para promover a industrialização do Brasil - e a continuidade do modelo dependente. Por outro, as lutas políticas e sociais em que as classes trabaIhadoras e setores da pequena-burguesia exigiam reformas estruturais aprofundavam a crise, engendrando, nos termos de Arcary (2004), uma "esquina perigosa da história". A solução se deu através de um golpe articulado por forças burguesas nacionais e internacionais, em 1으 de abril de 1964, que instaurou a Ditadura Militar, dando origem à autocracia burguesa, como conceituou Fernandes (2006). Dentre outras coisas, o Golpe provocou um retrocesso de grande monta em relação aos direitos humanos, políticos e sociais, incluindo os trabalhistas e sindicais.

\section{Golpe Militar e autocracia burguesa: ataque aos direitos trabalhistas e cerco à autonomia sindical}

A autocracia burguesa aprofundou o modelo de desenvolvimento dependente (IANNI, 1991) e, por via de consequência, da secular tradição heterônoma que marca a nossa formação social. Expressou de maneira cabal a exclusão política do conjunto dos trabalhadores - negando seus direitos enquanto classe - bem como as soluções pelo alto, também históricas no Brasil. O Golpe Militar reforçou o papel do mercado, autonomizou a economia da política, aprofundou a dependência externa. As linhas mestras do padrão concretizaram, para Netto (1991, p. 31), a "modernização conservadora" em acordo com os interesses "do monopólio capitalista: benesses ao capital estrangeiro e aos grandes grupos nativos, concentração e centralização em todos os níveis etc.".

Um dos primeiros elementos determinantes da condução econômica da autocracia burguesa foi a política de salários, voltada para o controle rigoroso dos acordos salariais privados e dos reajustes no âmbito do serviço público. Ou seja, o arrocho salarial, sob o argumento do combate à inflação (IANNI, 1981, p. 8). O segundo elemento, também estruturante, foi a restrição ao crédito; o terceiro diz respeito aos empréstimos internacionais, ao estímulo aos investimentos externos diretos (IEDs) e à exportação. Em uma relação íntima entre a economia e a política, tal condução foi alicerçada pela repressão sobre os trabalhadores urbanos e 


\section{Revista pll paעtg}

\} DITADURA MILITAR NO BRASIL - MARCONSIN, C. \}

rurais, definindo, por via de consequência, a economia política do lema "segurança e desenvolvimento". Para lanni (1981, p. 8):

Segurança, no sentido de 'segurança interna', envolve o controle e a repressão de toda organização e atividade política das classes assalariadas para que o capital monopolista tenha as mãos livres para desenvolver a acumulação. E desenvolvimento, no sentido do florescimento das 'forças do mercado', com a 'predominância da livre empresa no sistema econômico'. Foi assim que se definiu e consolidou, ao longo de todos os governos da ditadura, o núcleo principal do planejamento econômico estatal: o Estado foi posto a serviço de uma política de favorecimento do capital imperialista, política essa que se assentou na superexploração da força de trabalho assalariado, na indústria e na agricultura.

Mais do que nunca, a questão social foi tratada com o binômio repressão-assistência. Para garantir o arrocho salarial a autocracia burguesa utilizou-se da repressão policial, da censura, de prisão, tortura, desaparecimentos, mortes e de leis próprias de política salarial. Interveio em federações, confederações e sindicatos ${ }^{9}$, dando ênfase à função assistencial desses últimos, como ocorreu no Estado Novo, em detrimento da defesa de direitos dos trabalhadores. Para lanni (1991, p. 69), sob a égide da "ditadura do grande capital" plasmou-se "tanto uma relação arbitrária das condições de contrato de trabalho até a alteração do significado econômico e político do sindicato; tanto a militarização da fábrica como a generalização da violência policial". Nesse processo, entre 1964 e 1967 - primeiro momento da Ditadura Militar (NETTO, 1991) -, os direitos trabalhistas passaram por modificações regressivas.

Já nesse período, caracterizado por Netto (1991) como primeiro momento da Ditadura Militar, entre os vários ataques aos direitos trabalhistas, ganham relevância duas medidas: 1 ) arrocho salarial, através de reajuste anual baseado em índices unificados relativos à inflação, criado em 1964; 2) fim da estabilidade aos dez anos de serviço, que foi substituída pelo Fundo de Garantia por Tempo de Serviço (FGTS), através do Decreto $\mathrm{n}^{\circ}$ 53.914, de 02/05/64, que aparecia como se fosse uma opção aos trabalhadores (a Lei 5107 de setembro de 1966 colocou esse "fundo unificado de reservas" sob a administração do Banco Nacional de Habitação).

O FGTS é considerado por Maccalóz (1997) como a primeira medida de flexibilização da legislação trabalhista, exigência do capitalismo internacional. Também para Rodrigues (2008, p. 72) a extinção da "estabilidade no emprego" e a instituição do "Fundo de Garantia por Tempo de Serviço" são elementos de "flexibilização" da legislação para atender "às exigências do Fundo Monetário Internacional, entre 1964 e 1968".

${ }^{9}$ Entre 1964-1970 houve 652 intervenções sindicais (GIANNOTTI, 2007). 
No âmbito da organização sindical, o ataque frontal dirige a dois aspectos fulcrais: 1) proibição do direito de greve, com a Lei $\mathrm{n}^{\mathrm{O}} 4330$ de junho de 1964, conhecida como Lei antigreve (BRASIL, 1964); 2) o cerceamento da autonomia sindical, através de alterações regressivas na Consolidação das Leis do Trabalho (CLT), regidas pela Doutrina de Segurança Nacional, como mostra o artigo 528, alterado pelo Decreto-Lei no 3 de 27/ 01/1966, que institui a intervenção do Estado nos sindicatos (BRASIL, 1966):

Ocorrendo dissídio ou circunstâncias que perturbem o funcionamento de entidade sindical ou motivos relevantes de segurança nacional, o Ministro do Trabalho e Previdência Social poderá nela intervir, por intermédio de Delegado ou de Junta Interventora, com atribuições para administrá-la e executar ou propor as medidas necessárias para normalizar-lhe o funcionamento. (BRASIL, 1966).

A Ditadura Militar ou a autocracia burguesa esvaziou os sindicatos interferindo neles, prendendo e assassinando trabalhadores, afastando as correntes de esquerda. Entretanto, não conseguiu aniquilá-las completamente, deslocando as mesmas para a organização autônoma dos trabalhadores a partir do local de trabalho. Nesse caminho, nos anos de 1967 e 1968, segundo Mattos (2002, p. 70), a esquerda formou "movimentos intersindicais contrários à política salarial do governo, sendo o mais conhecido o denominado Movimento Intersindical contra o Arrocho (MIA)", que lutava pelo fim do arrocho salarial, livre negociação e reforma agrária, entre outras reivindicações. Em 1968, observa-se uma retomada do movimento grevista, com as greves de Contagem (MG) e a de Osasco (SP) ${ }^{10}$, que objetivavam o fim do arrocho salarial e a criação do contrato coletivo de trabalho, marcando significativamente a memória do movimento sindical e político brasileiro ainda hoje (GIANNOTTI, 2007, p. 198-200). Data do mesmo período a contestação política dos estudantes para ampliação do sistema educacional público, com passeatas e atos diversos ${ }^{11}$.

Para Netto (1991, p. 37), na época, formou-se uma frente ampla de sindicalistas, estudantes e deputados oposicionistas, "sinal inequívoco da ruptura do pacto contrarrevolucionário". No mesmo processo, "por fora da política institucional, condensavam-se polos (básica, mas não exclusivamente, de extração pequeno-burguesa), que concebiam a liquidação do arbítrio como ultrapassagem da dominação burguesa". Embora a ação dessa frente ampla de oposição não incidisse "nos centros decisórios do

\footnotetext{
${ }^{10}$ A greve de Contagem (MG) durou uma semana e, mesmo com a dura repressão, obteve $10 \%$ de abono estendido a todo o país em julho de 1968 como "abono emergencial". Em Osasco, a greve durou seis dias, o exército ocupou a cidade e as fábricas, interveio no Sindicato dos Metalúrgicos, prendendo sua direção e 500 trabalhadores (GIANNOTTI, 2007).

${ }^{11}$ Data desse período a morte do estudante Edson Luís (1968), provocando, em todo o país, uma onda de protestos. Em junho do mesmo ano, a Passeata dos Cem Mil tornou-se a maior manifestação ocorrida até então, sendo organizados atos em capitais como Recife, São Paulo etc., sempre acompanhados de grande repressão, sendo que, naquele ano, sete manifestantes foram mortos, a maioria no Rio de Janeiro.
} 


\section{Revista pll paעtg}

\} DITADURA MILITAR NO BRASIL - MARCONSIN, C. \}

Estado", ainda segundo Netto (1991, p. 38), a autocracia burguesa respondeu com a instauração de uma "nova ordem", com a total "militarização do Estado e da sociedade".

Através do Ato Institucional $\mathrm{n}^{\circ} 5$ (Al-5), fechou o Congresso, cassou mandatos de sindicalistas e deputados oposicionistas, prendeu estudantes, deixou os direitos políticos individuais sujeitos à suspensão por 10 anos, decretou o fim do habeas corpus etc. (BRASIL, 1968a). O ano de 1968 tornou-se um marco da Ditadura abrindo-se, desde então, o "genuíno momento da autocracia burguesa": o que fora uma ditadura reacionária, para Netto (1991, p. 38), se transformou em um regime politico de nítidas características fascistas.

No contexto sócio-histórico, caracterizado por Netto (1991) como segundo momento da Ditadura, foi que o "milagre brasileiro" foi engendrado. Combinado à política repressiva de segurança nacional, alavancouse o país para um modelo de desenvolvimento mais efetivo, fazendo avançar a acumulação capitalista. A ação da autocracia burguesa, então, de acordo com Antunes (1988, p. 128), voltou-se para a aceleração, através do "milagre", da construção de "um setor dinâmico no parque industrial brasileiro", criando indústrias que concentravam grande número de trabalhadores e, por sua vez, concentravam-se, também elas, em determinadas regiões, como no ABC paulista, por exemplo. Mas também, como mostra Kucinski (1982, p. 177), "nos distritos industriais de Minas Gerais, Rio de Janeiro e, em menor escala, nas novas cidades industriais no interior de São Paulo". Englobavam indústrias automobilísticas, metalúrgicas, químicas, eletromecânicas etc.

Nesse período, para Antunes (1988, p. 128) foi constituído "um proletariado inserido na grande indústria moderna", a qual possuía uma "maior composição orgânica de capital" e que apresentava "níveis de qualificação do trabalho superiores aos da indústria tradicional". O autor mostra, ainda, que o emprego nas grandes empresas multinacionais era mais atraente que nas nacionais, principalmente nas médias e pequenas. Entretanto, com o arrocho salarial, os trabalhadores viviam uma "tendência persistente à depreciação salarial, à constante subtração do quantum referente à remuneração do trabalho em benefício do mais-valor apropriado pelo capital monopólico" acompanhada do crescimento vertiginoso da produtividade ${ }^{12}$. Trata-se, para Antunes (1988, p. 163-164), da "superexploração do trabalho", combinando longas jornadas, que atingiam até 56 horas em cinco dias de trabalho, "com uma intensidade extenuante do processo produtivo - num parque industrial tecnologicamente avançado e com significativa concentração operária". Ou seja, a longa luta pela redução da jornada se mantém no período. Além disso, observa-se "altas taxas de turn-over", rotati-

\footnotetext{
${ }^{12}$ Entre 1968-1974 o aumento do número de veículos produzido por trabalhador nas indústrias automotivas foi de $71 \%$ (ANTUNES,1988).
} 


\section{Aevistg all paUtg}

\} DITADURA MILITAR NO BRASIL - MARCONSIN, C. \}

vidade decorrente também de um desemprego historicamente significativo que "favorece e possibilita a tendência constante à depressão salarial" (ANTUNES, 1988).

Nesse período, mais ataques aos direitos do trabalho foram desfechados, como o reforço da Política de Arrocho salarial que, imposta em 1964, tornou-se permanente pela Lei 5451 de 1968 (BRASIL, 1968b), sendo reformulada e aperfeiçoada em 1974 pela Lei 6147 (BRASIL, 1974b); a instituição do regime de trabalho temporário para atender necessidade transitória de substituição de pessoal regular e permanente ou para acréscimo extraordinário de serviços, pela Lei no 6019 de 1974, com direitos reduzidos em relação aos contratos por tempo indeterminado (BRASIL, 1974a).

Do ponto de vista da organização e das lutas dos trabalhadores, nesse segundo momento mais do que nunca, a economia política imprescindível ao capital monopolista aprofundou a proibição de greves, a intervenção e o desmantelamento das organizações e movimentos políticos, sindicais e populares, bem como prisão, deportação e desaparecimento de lideranças. Mas, também, as lideranças viveram outra modalidade de repressão: devido ao fato de terem seus nomes incluídos nas denominadas "listas negras", organizadas pelas empresas com a colaboração da polícia e dos próprios sindicalistas impostos pela autocracia burguesa, passaram a ter grandes dificuldades para encontrar emprego (IANNI, 1981, p. 69). Ao mesmo tempo, acentuou-se a função de assistência nos sindicatos. Para Mattos (2002, p. 73):

Após nova leva de intervenções, os governos militares, em inícios dos anos 1970, trataram de valorizar um 'novo' modelo de atuação sindical pautado pela ação exclusivamente assistencial e afinada com as ideias de crescimento econômico como pré-requisito para uma posterior política redistributiva. Este lado assistencial dos sindicatos seria fortalecido pela injeção de recursos do governo, via financiamentos e doações e reforçado pela conjuntura de início da crise da saúde pública e fim dos Institutos de Aposentadoria e Pensões.

Juntamente à política de interdição da participação dos trabalhadores, de suas organizações e de partidos de esquerda ${ }^{13}$, a autocracia burguesa foi obrigada a desenvolver ações para obtenção do consenso, na sociedade, assimilando reivindicações históricas da classe trabalhadora. Entretanto, as reivindicações se davam de forma a não afetar os interesses monopolistas; antes, davam-lhes grandes vantagens, no mesmo movimento de mistificação dos direitos que eram mostrados como favor ou outorga. Citase, como exemplo, a cobertura previdenciária à quase totalidade dos traba-

\footnotetext{
${ }^{13}$ A ditadura perseguiu com prisões arbitrárias, exílios e assassinatos integrantes dos grupos de luta armada, mas também de trabalhadores organizados e de comunistas ligados à orientação do PCB, que não optou por essa forma de luta, mas pela luta política, por mais limitada e limitante que fosse no auge da repressão.
} 


\section{Revista pll paעtg}

\} DITADURA MILITAR NO BRASIL - MARCONSIN, C. \}

Ihadores urbanos, incluindo-se alguns direitos para os empregados domésticos. Através do Decreto-Lei no 926 de 10 de outubro de 1969, os trabalhadores rurais passaram a ter Carteira de Trabalho, sendo que uma parte deles (não todos) passou a ter direitos previdenciários através do Fundo Rural (FUNRURAL), desde a década de 1970 (BRASIL, 1969).

Por outro lado, se "as greves por categoria e a chegada de grupos políticos de esquerda às direções sindicais eram impossíveis, dado o alcance da repressão", isso não significou silêncio e inatividade totais, porque "os ativistas mais combativos não desistiram do trabalho de organização dos trabalhadores nas empresas", como aponta Mattos (2002, p. 75). Giannotti (2007) também fala das comissões de fábricas, organizadas pelos ativistas, como construção da luta de dentro para fora. Da situação de superexploração vivenciada para trabalhadores que produziam o "milagre econômico", potencializada pelo trabalho de base dos ativistas, resultaram diversos movimentos grevistas por empresas, de pequena duração e com motivações em geral ligadas a atrasos de pagamentos ou acidentes nas plantas industriais ${ }^{14}$. Ainda com base em Mattos (2002, p. 76), observamos que as lutas "subterrâneas" confrontavam a Ditadura, os dirigentes sindicais ligados à Ditadura e a intransigência patronal no âmbito das fábricas. Esse processo, cumulativamente, trouxe resultados significativamente diferentes na transição dos anos 1970 para 1980, com o irromper de greves, especialmente no ABC paulista, de forma conjugada à crise do capital, no Brasil, incidindo na dinâmica inteira da autocracia burguesa.

\section{A crise do capital incide sobre a autocracia burguesa: as lutas por direitos ganham a cena política novamente}

O irromper da crise internacional do capital, que se inicia na transição dos anos 1960 para 1970, incidiu no Brasil mais efetivamente a partir de meados para o final da década de 1970, levando ao esgotamento do padrão de acumulação desenvolvido pela autocracia burguesa, incidindo em sua dinâmica inteira. As fissuras políticas frente à crise atingiram o próprio bloco no poder, já que o tripé de sustentação - monopólios nacionais, internacionais e setor produtivo estatal - negava-se a assumir os custos dela. Observa-se, aí, a "turbulência concentrada" que, segundo Fernandes (1986, p. 25), "vem de cima e se multiplica velozmente graças ao poder real dos ricos e poderosos". Behring (2003, pp. 131-132) aponta o "recrudescimento do endividamento externo" como elemento central da crise brasileira e da América Latina, no período. Como os empréstimos internacionais foram estruturantes da economia da autocracia burguesa, a

\footnotetext{
${ }^{14}$ Os levantamentos realizados no período identificam mais de duas dezenas de movimentações dos trabalhadores, sejam greves curtas e operações tartaruga em várias empresas entre 1973 e 1974 (GIANNOTTI, 2007).
} 


\section{peVistg all paUtg}

\} DITADURA MILITAR NO BRASIL - MARCONSIN, C. \}

crise internacioanal do capital provocou o aumento da taxa de juros, levando a uma séria crise de liquidez no país, trazendo, centralmente, o aumento exacerbado da dívida externa (GIANNOTTI, 2007). Como decorrência, a inflação disparou, sendo acompanhada por um aumento vertiginoso do desemprego, atingindo seu auge no ano de 1983.

Entre os trabalhadores a insatisfação cresce, atingindo todas as suas camadas, espraiando-se pelo conjunto da sociedade brasileira ${ }^{15}$. Frente a esse quadro, a Ditadura engendrou um processo de abertura, lenta e gradual, sob seu controle. Todavia, além do aprofundamento da crise internacional um elemento inesperado, no período, fez precipitar a abertura pretendida pela autocracia burguesa: o movimento grevista do ABC paulista. Trazendo a "reinserção da classe operária", como aponta Netto (1991, p. 42), o movimento desses trabalhadores abalou o projeto da autocracia burguesa. Também para Antunes (1988, p. 126-128), o movimento dos operários de fins dos anos 1970 interferiu no "processo de auto-reforma do Estado burguês", pois as ações grevistas defensivas, construídas nas fábricas ao longo da década de 1970, desaguaram nas "Greves de Maio" em 1978, seguindo-se, em 1979, pela "Greve Geral Metalúrgica" e as "Greves de 1980". Nessas greves, as reivindicações abrangiam itens diversos, mas centravamse nos aumentos salariais, redução da jornada de trabalho, vigência da Convenção Coletiva de Trabalho e reconhecimento e estabilidade para os delegados sindicais. Mas as liberdades democráticas, com grande centralidade no direito de greve, norteavam as lutas e os movimentos grevistas no período.

Assim, além das lutas de resistência durante o período, podemos dizer que as greves metalúrgicas de fins de 1970 e inícios de 1980 obtiveram conquistas para os que as deflagraram. Porém, também rebateram em todas as outras categorias operárias, em outras camadas de trabalhadores, como dos transportes, da construção civil, até aquelas alocadas nas universidades e instituições públicas em geral. Essas lutas, segundo Kucinski (1982, p. 129), contribuíram para "consolidar o apoio da opinião pública em geral a favor das greves operárias e contra o governo". Entendemos que elas expressavam a necessidade de democracia na sociedade brasileira. Coelho (2005, p. 40) considera que o esgotamento do "milagre" e consequente acirramento das lutas dos trabalhadores tornou crucial, para a burguesia, "transitar" para uma "outra modalidade de dominação [...], o que explica a atuação destacada de políticos do regime na montagem de estratégias de transição".

Para Netto (1991, p. 42), a "reemergência do proletariado urbano", desde fins da década de 1970, feriu a legalidade imposta pela autocracia burguesa, deflagrando uma "radicalização na oposição democrática - que, então e aliás, inicia um giro explícito de aproximação à classe operária".

${ }^{15}$ Nas eleições de 1974, os candidatos da ARENA (partido da ditadura) sofreram significativa derrota. 


\section{Revista pll paעtg}

\} DITADURA MILITAR NO BRASIL - MARCONSIN, C. \}

Nesse processo, observa-se uma efervescência político-ideológica de grandes proporções na sociedade brasileira, já que as lutas dos trabalhadores potencializaram outras já em andamento, encerrando a década de 1970 com uma relação de forças significativamente diferente de seus inícios, possibilitando avanços dos direitos sociais, em geral, e trabalhistas e sindicais, em particular, significando o início do fim da Ditadura Militar em nosso país.

Coelho (2005, p. 45) entende que as greves e a "emergência dos movimentos sociais trouxeram novos personagens" para a cena pública e, "com eles, novas demandas, novos valores, novas práticas", o que apressou "a política, encurtando os prazos da transição", e deu à correlação de forças "um conteúdo novo".

O adjetivo 'novos' tem um sentido preciso: após anos de estreitamento dos espaços de ação pública, os movimentos da classe trabalhadora ressurgem nos conflitos em céu aberto e renovam a política do país com a sua simples presença. Abre-se um novo momento na história política quando forças sociais poderosas procuram meios para se expressar (COELHO, 2005, p. 45).

Apressando a transição, as lutas ocorridas em fins dos anos de 1970, percorrendo toda a década de 1980, "trouxeram novos sujeitos para a cena pública", forjando "novos sujeitos coletivos", mas também provocaram a reelaboração de laços de identidade de classe (COELHO, 2005, p. 46). Relacionando democracia - o mote das lutas no período contra a Ditadura - com igualdade de direitos, os trabalhadores organizados ganharam eleições em sindicatos e associações, mudando em grande parte as direções e seus encaminhamentos. Desse processo como um todo originase o Partido dos Trabalhadores (PT) e a Central Única dos Trabalhadores (CUT), por exemplo, ainda em inícios dos anos 1980. Em meados de 1985, observa-se a criação do Movimento dos Trabalhadores Sem Terra (MST).

Mas a manutenção na ilegalidade dos Partidos Comunistas - Partido Comunista Brasileiro (PCB) e Partido Comunista do Brasil (PC do B) na reforma partidária, ocorrida em 1979, demonstra que a correlação de forças não se tornou suficiente para a superação do caráter inconcluso da democratização da sociedade brasileira. Além disso, outros elementos deixaram legados significativos para os direitos dos trabalhadores. Dentre eles, ganha relevância a derrota das Eleições Diretas, em 1984, realizadas através do Colégio Eleitoral ${ }^{16}$ e da Assembleia Nacional Constituinte para elaboração da nova Constituição Federal.

De fato, a Carta Magna de 1988 foi elaborada por um Congresso Constituinte, eleito em 1986. Concordamos com Teixeira (2006, p. 96-

${ }^{16}$ O Colégio Eleitoral escolheu, de forma indireta, Tancredo Neves (PMDB) e José Sarney (PDS) \% que substituiu o partido da Ditadura (ARENA), sendo que Tancredo (PMDB) morreu antes de tomar posse e Sarney (PSD) governou o Brasil de 1985 até a posse de Collor de Mello em 1990. 


\section{peVistg all paUtg}

\} DITADURA MILITAR NO BRASIL - MARCONSIN, C. \}

97), para quem os elementos conservadores e restauradores impostos pela autocracia burguesa tornaram-se presentes tanto na transição - através do Colégio Eleitoral eleito ainda durante a Ditadura Militar - quanto na Constituição Federal de 1988, permanecendo presentes ainda hoje. Antunes (1991, p. 74) também entende que a "Constituição, promulgada em outubro de 1988 consolidou o trânsito da ditadura militar para o conservadorismo civil", pois a "maioria parlamentar dominante impediu que mudanças substantivas fossem conquistadas e manteve, no essencial, o caráter conservador da Carta Constitucional". Entretanto, mesmo o próprio Antunes (1991, p. 74) considera que, apesar do caráter conservador da Constituição Federal de 1988, seria um erro "ignorar o fato de que as pressões vindas de baixo também tiveram um papel no processo de transição e condicionaram muitos dos seus resultados", incorporando importantes direitos sociais à Constituição Federal, em 1988. Entendemos, também, que embora a Constituição não tivesse provocado transformações profundas como pretendiam as forças sociais comprometidas com elas, trouxe avanços - legados inegáveis dos trabalhadores em luta contra a Ditadura Militar. Podemos citar as inovações no que diz respeito às áreas da Educação, pré-escolar, fundamental e superior, aos aspectos ambientais e da seguridade social, que ganhou novo marco legal, compreendendo o tripé saúde, previdência e assistência. Houve avanços, também, em termos de direitos políticos e de controle social, importante mecanismo de democratização da sociedade, obtidos pelos trabaIhadores através de pressões combinando lutas e ações junto a parlamentares, através da instituição dos conselhos de saúde, assistência e previdência.

Em relação aos direitos trabalhistas, foram conquistados: segurodesemprego (embora restrito, abrangendo apenas o desemprego involuntário); jornada de 6 horas para regimes de turnos; ampliação da licença maternidade para 120 dias; licença-paternidade de cinco dias; redução da jornada de trabalho para 44 horas semanais; adicional de férias de 1/3; estabelecimento da hora extra a $50 \%$. Houve mudanças também relativas à organização sindical: em seu artigo $8^{\circ}$, o funcionalismo público obtém direito à sindicalização; amplia-se a liberdade e a autonomia sindical, impedindo o poder público de intervir nos sindicatos. Um direito fundamental também foi conquistado: o direito de greve, superando a Lei no 4330 de junho de 1964, conhecida como a lei antigreve. Ao mesmo tempo, "foram estendidos ao campo vários direitos sindicais anteriormente restritos ao mundo urbano" (ANTUNES, 1991, p. 74). Entretanto, limitações foram mantidas:

[...] a unicidade sindical, o monopólio da representação, o imposto sindical e o poder normativo da Justiça do Trabalho. Esta agora decide quais são as categorias essenciais, que podem ou não fazer greve. Ao mesmo tempo, muitos direitos são colocados na Carta, porém, sem qualquer regulamentação. Essas regulamentações viriam no futuro [...]. (GIANNOTTI, 2007, p. 257). 


\section{Considerações Finais}

O protagonismo dos trabalhadores organizado, historicamente, obteve a ampliação de direitos políticos - como liberdade de reunião, criação de partidos, filiação partidária e outros - antes restritos aos proprietários. A partir da metade do século XIX, em conformidade com Bussinger (1997, p. 29), os direitos políticos deixaram de ser monopólio da burguesia e "produto secundário dos direitos civis". Não é por acaso que o movimento operário moderno, como aponta Hobsbawm (2005), descende do iluminismo e do racionalismo construídos no século XVIII, já que ele se vê obrigado a confrontar-se com a burguesia que, quando se torna classe dominante, abandona os compromissos do iluminismo para a modernidade. Os direitos políticos de organização foram sendo obtidos e consolidados no processo mesmo em que as lutas por direitos no trabalho avançavam, e mereceram destaque, em nosso debate, as reivindicações iniciais pela diminuição da jornada de trabalho.

Nesse processo como um todo, a crise mundial de 1920, a Primeira Guerra Mundial e a Revolução Russa, em 1917, foram fundamentais. É demonstrativo disto a concessão, em quase toda a Europa, da exigência principal dos agitadores socialistas desde 1889, por exemplo: "o dia de trabalho de oito horas" (HOBSBAWM, 1996, p. 128). Ou seja, a possibilidade de revoluções como a Russa não afetou apenas aos países da Europa, mas ao mundo capitalista. Tendo em vista o perigo vermelho, foi criada em 1919, a Organização Internacional do Trabalho (OIT), objetivando padronizar a intervenção estatal nas relações de trabalho (RODRIGUES, 2006). Outubro de 1917, pois, inaugurou um período diferente na relação de forças entre as classes, permitindo avanços para os direitos dos trabalhadores, no mundo capitalista como um todo, incluindo o Brasil.

Em terras brasileiras, a luta dos trabalhadores por direitos trabaIhistas e sindicais, mas também por liberdades democráticas, que se inica desde fins do século XIX e inícios do XX, conjuga-se e tem sido, portanto, historicamente árdua.

Fernandes (2006, p. 244) mostra que, no desenvolvimento capitalista brasileiro, as divergências entre setores da burguesia eram suportadas, mas as diferenciações postas pelo proletariado eram tratadas como uma "demonstração de lesa-majestade".

[...] as reservas da opressão e de repressão de uma sociedade de classes em formação foram mobilizadas para solapá-la e para impedir que as massas populares conquistassem, de fato, um espaço político próprio, 'dentro da ordem'. Essa reação não foi imediata, ela teve larga duração, indo do mandonismo, do paternalismo e do ritualismo eleitoral à manipulação dos movimentos políticos populares, pelos demagogos conservadores ou oportunistas e pelo condicionamento estatal do sindicalismo. (FERNANDES, 2006, p. 244). 


\section{peVistg all paUtg}

\} DITADURA MILITAR NO BRASIL - MARCONSIN, C. \}

Mergulhados nessa realidade, os trabalhadores desenvolveram suas lutas por direitos trabalhistas de maneira persistente e renhida, obrigando a ortodoxia liberal, também em terras brasileiras, a defrontar-se com o problema da democracia, sempre de maneira resistente. Ao longo do tempo, os trabalhadores buscaram conquistar direitos trabalhistas e liberdade de organização sindical, enfrentando muita repressão. Demonstra isso a ação repressiva do Estado Novo sobre os trabalhadores organizados, que se colocavam contrários à conduçao econônico-política do período e à autocracia burguesa que, sob a égide da Lei de Segurança Nacional, amordaçou o movimento sindical com repressão e intervenções.

O Golpe Militar de 1964, de fato, materializou-se em um quadro de forças internacionais e nacionais de acirramento da contradição entre as necessidades postas pela acumulação capitalista e "a modalidade de intervenção, articulação e representação das classes e camadas sociais no sistema de poder político" (NETTO, 1991, p. 26). O grande capital pode desenvolver-se à sombra da Ditadura, impondo a superexploração da força de trabalho brasileira. Entretanto, à repressão e à cooptação desencadeadas durante sua vigência, resistências importantes por parte dos trabalhadores organizados se colocaram.

A partir da crise da Ditadura, esses setores se fortaleceram e organizaram lutas de confronto, com conquistas fundamentais, na prática, como o direito de greve, por exemplo, apressando a transição desejada pela Ditadura. Confirmando que a luta é árdua, se a elaboração da Constituição Federal de 1988 fechou o ciclo da Ditadura Militar, isso não garantiu muitos direitos fundamentais. Concordando com Antunes (1991, p. 74), a Constituição Federal de 1988 trouxe "pontos de avanço para os trabalhadores", mas os representantes do capital obstaculizaram muitos deles e "procuram, ainda hoje, obstar e inviabilizar através de legislação complementar" a sua materialização.

Podemos concluir, então, que a luta de classes não se esgotou no processo vivido contra a Ditadura; continua em todos os momentos da vida em sociedade, não importando a forma de dominação burguesa. Frente a todos esses elementos, como estudiosos dos direitos do trabalho, no âmbito do Serviço Social, torna-se imprescindível que os estudos e as análises sobre a questão continuem a avançar, buscando captar a realidade numa perspectiva de totalidade. Isto é, procurando contribuir, assim, para que a verdade sobre a Ditadura Militar apareça para amplos setores da sociedade brasileira e para que nunca se esqueçam desse período discricionário, violento e arbitrário para o conjunto da esquerda e dos trabalhadores brasileiros. 


\section{Referências}

ANTUNeS, R. O que é sindicalismo. Col. Primeiros Passos, vol. 24. São Paulo, Abril Cultural, Brasiliense, 1985.

ANTUNES, R. A rebeldia do trabalho: o confronto operário no ABC paulista: as greves de 1978/80. São Paulo/Campinas: Ensaio/Editora da UNICAMP, 1988

. O novo sindicalismo. São Paulo: Brasil Urgente, 1991.

ARCARY, V. As esquinas perigosas da história: situações revolucionárias em perspectiva marxista. São Paulo: Xamã, 2004.

BEHRING. E. R. Brasil em contrarreforma: desestruturação do Estado e perda de direitos. São Paulo: Cortez, 2003.

BRASIL. Lei no 4.330 de $1^{\circ}$ junho de 1964. Constituição da República Federativa do Brasil, 1964.

. Decreto-Lei no 3 de 27 de janeiro de 1966. Consolidação das Leis do Trabalho, 1966.

. Lei $n^{0} 5.451$ de 12 de junho de 1968. DOU de 14/6/1968b.

. Ato Institucional no 5 de 13 de dezembro de 1968. Constituição da República Federativa do Brasil, 1968a.

. Decreto-Lei no 926 de 10 de outubro de 1969. Consolidação das Leis do Trabalho, 1969.

. Lei $n^{\circ} 6.147$ de 29 de novembro de 1974. DOU de 2/12/1974b.

Trabalho, 1974a.

BUSSINGER, V. V. Fundamentos dos direitos humanos. Revista Serviço Social e Sociedade, São Paulo, no 53, ano XVII, p. 9-45, 1997.

COELHO, E. Uma esquerda para o capital: crise do marxismo e mudanças nos projetos políticos dos grupos dirigentes do PT (1979-1998). 535 f. Tese (Doutorado em História) - UFF, Niterói, 2005.

DIAS, E. F. Política brasileira: embate de projetos hegemônicos. Ed. Sundermann, São Paulo, 2006.

FERNANDES, F. A revolução burguesa no Brasil. Petrópolis: Vozes, 2006. . Que tipo de República?. São Paulo: Brasiliense, 1986.

GIANNOTTI, V. História das lutas dos trabalhadores no Brasil. Rio de Janeiro: Mauad X, 2007.

HOBSBAWM, E. A Era dos Extremos: o breve século XX - 1914-1991. São Paulo: Companhia das Letras, 1996. 


\section{Aevistg all paUtg}

\} DITADURA MILITAR NO BRASIL - MARCONSIN, C. \}

HOBSBAWM, E. Os trabalhadores: estudos sobre a história do operariado. São Paulo: Paz e Terra, 2000.

- Mundos do trabalho: novos estudos sobre História Operária. São Paulo: Paz e Terra, 2005.

IANNI, O. A ditadura do grande capital. Rio de Janeiro: Civilização Brasileira, 1981.

. Estado e planejamento econômico no Brasil. Rio de Janeiro: Civilização Brasileira, 1991.

KUCINSKI, B. Abertura: a história de uma crise. São Paulo: Brasil Debates, 1982.

MACCALÓZ, M. S. Globalização e flexibilização. In: MACCALÓZ, M. S. et al. Globalização, neoliberalismo e direitos sociais. Rio de Janeiro: Destaque, 1997.

MARCONSIN, C. Cerco aos direitos trabalhistas e crise do movimento sindical no Brasil contemporâneo. 262 f. Tese (Doutorado em Serviço Social) - Escola de Serviço Social - ESS/UFRJ, Rio de Janeiro, 2009.

MATTOS, M. B. Trabalhadores e sindicatos no Brasil. Rio de Janeiro: Vício de Leitura, 2002.

MARX, K. O Capital. Crítica da Economia Política. São Paulo: Nova Cultural, 1988.

. O "coup de main" de Luís Bonaparte. In: FERNANDES, F. (Org.). $\overline{M a r x / E n g e l s, ~ c o l . ~ H i s t o ́ r i a . ~ S a ̃ o ~ P a u l o: ~ A ́ t i c a, ~} 1983$.

NETTO, J. P. Ditadura e Serviço Social: uma análise do Serviço Social no Brasil pós-64. São Paulo: Cortez, 1991.

. Capitalismo monopolista e Serviço Social. São Paulo, Cortez, 1992.

RODRIGUES, N. Desmonte do Estado e do Direito do Trabalho: resis-tência internacional. Palestra. Grupo de Pesquisa Seguridade Social, Orga-nismos Internacionais e Serviço Social. Rio de Janeiro, LOCUSS, ESS, CFCH, UFRJ, set. 2006.

. Magistratura e neoliberalismo: os juízes do trabalho e a ideologia da destruição. 181f. Dissertação de Mestrado em Sociologia e Direito. UFF, Niterói (RJ), 2008.

TEIXEIRA, A. M. de P. Previdência Social no Brasil: da revolução passiva à contrarreforma. 252 f. Tese (Doutorado em Serviço Social) - UFRJ, Rio de Janeiro, 2006.

VIANA, L.W. Liberalismo e sindicato no Brasil. Rio de Janeiro: Paz e Terra, 1978. 


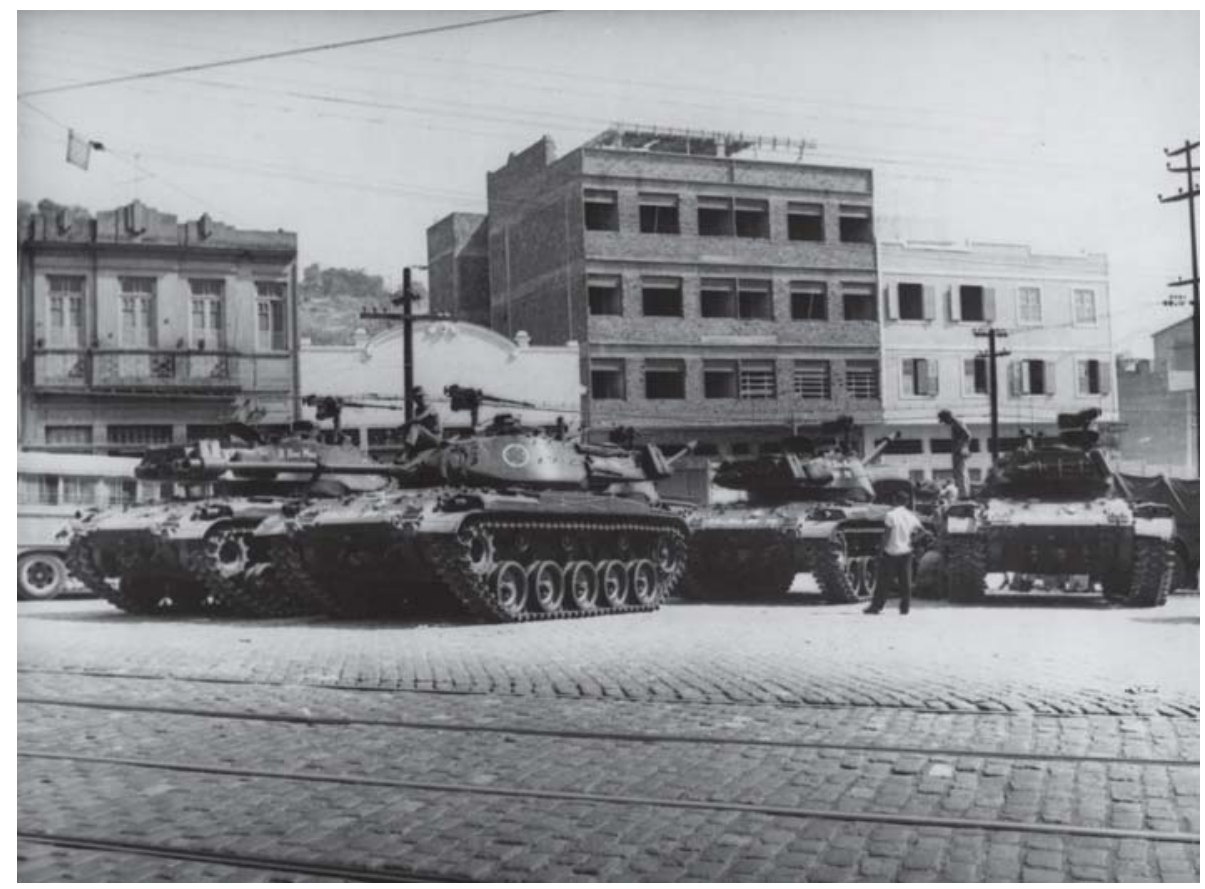

Cerco ao Sindicato dos Metalúrgicos. Rio de Janeiro. 1964. Correio da Manhã. Arquivo Nacional 